\title{
SIMULASI DAMPAK LIBERALISASI PERDAGANGAN BILATERAL RI-YAMAN TERHADAP PEREKONOMIAN INDONESIA DAN YAMAN: SEBUAH PENDEKATAN SMART MODEL
}

\author{
Sulthon Sjahril Sabaruddin \\ Kedutaan Besar Republik Indonesia di Sana'a \\ Kementerian Luar Negeri Republik Indonesia \\ e-mail: sulthon.sjahril@kemlu.go.id
}

\begin{abstract}
This paper is intended to evaluate the impact of Indonesia's trade liberalization with Yemen on the Indonesian economy. In order to evaluate the impact of the Indonesian economy, we analyzed it through the analysis method of Software for Market Analysis and Restrictions on Trade (SMART) model. The result of the analysis, the scenario of the impact of trade liberalization of RI-Yemen on the economy of Indonesia with complete tariff dismantlement, by utilizing the analysis of consumer surplus change, the change of import and export, and the change of tariff income can be concluded that the liberalization of RI-Yaman trade with zero tariff has very positive impact to the economy Indonesia and quite positively to the Yemeni economy. This passage is a form of anticipation of possible policy changes when the political, economic and security situation in Yemen has recovered.
\end{abstract}

Keywords: free trade, partial balance analysis, trade liberalization

\begin{abstract}
ABSTRAK
Tulisan ini dimaksudkan untuk mengevaluasi dampak liberalisasi perdagangan Indonesia dengan Yaman terhadap perekonomian Indonesia. Guna mengevaluasi dampak yang ditimbulkan terhadap perekonomian Indonesia, dianalisis melalui pendekatan metode analisis model Software for Market Analysis and Restrictions on Trade (SMART). Hasil analisis skenario dampak liberalisasi perdagangan RI-Yaman terhadap perekonomian Indonesia dengan complete tariff dismantlement, dengan memanfaatkan analisa perubahan consumer surplus, perubahan impor dan ekspor, serta perubahan pendapatan tarif dapat disimpulkan bahwa liberalisasi perdagangan RI-Yaman dengan nol tarif berdampak sangat positif terhadap perekonomian Indonesia dan cukup positif terhadap perekonomian Yaman. Telahaan ini merupakan bentuk antisipasi kemungkinan perubahan kebijakan manakala situasi politik, ekonomi, dan keamanan di Yaman telah pulih kembali.
\end{abstract}

Kata kunci: analisis keseimbangan parsial, liberalisasi perdagangan, perdagangan bebas

Hubungan bilateral RI-Yaman selama ini terjalin dengan baik mengingat kedua bangsa memiliki kaitan emosional dan historis yang erat, khususnya terkait dengan sejarah penyebaran agama Islam ke Indonesia di masa lampau (Kedutaan Besar Republik Indonesia di Sana'a, 2016). Penyebaran Islam merupakan salah satu proses yang sangat penting dalam sejarah Indonesia. 
Bangsa Yaman dari wilayah Hadramaut telah hadir di nusantara sejak abad ke-11 Masehi, dan bahkan ada yang menyatakan sejak abad ke-9 Masehi, dengan tujuan berniaga serta menyebarkan agama Islam. Orang-orang dari Yaman Hadramaut dikenal sebagai sayyid (gelar menandakan keturunan Nabi Muhammad SAW) dan pedagang yang cakap dengan jaringan internasional yang membentang hingga Timur Tengah dan Afrika Timur (Ricklefs, 2005).

Dalam hubungan diplomatik, Pemerintah Republik Yaman selalu menganggap Indonesia sebagai brotherly country. Republik Yaman merupakan salah satu negara yang pertama (tahun 1948) dalam memberikan pengakuan terhadap kemerdekaan dan kedaulatan negara Republik Indonesia serta hampir selalu mendukung pencalonan Indonesia di berbagai forum internasional. Selain itu, terdapat warga Indonesia keturunan Arab Yaman di Indonesia dan mencapai 9 juta orang. Hal ini tentu merupakan sebuah modal besar bagi Indonesia untuk terus meningkatkan hubungan di semua bidang.

Pada tanggal 22 Mei 1990, Yaman Utara dan Yaman Selatan bersatu menjadi satu negara dengan nama Republik Yaman. Setelah itu, Pemerintah Yaman mengubah status Konsulat Jenderal Yaman Selatan di Jakarta menjadi Kedutaan Besar Republik Yaman. Sedangkan Kantor Kedutaan Besar RI (KBRI) di Sana'a ditetapkan berdasarkan Keputusan Presiden RI Nomor: 12 Tahun 1992 tanggal 12 Pebruari 1992, dan resmi dibuka pada tanggal 16 Nopember 1992 (Kedutaan Besar Republik Indonesia di Sana'a, 2016).

Eratnya hubungan diplomatik kedua negara juga ditandai dengan kunjungan timbal balik para pejabat tinggi kedua negara. Tercatat Presiden RI Abdurrahman Wahid melakukan kunjungan kenegaraan ke Yaman pada tahun 2001, sedangkan Presiden Yaman melakukan kunjungan kerja ke Indonesia pada tahun 1998, 2009, dan 2016. Selain itu, Wakil Presiden RI, Hamzah Haz melakukan kunjungan ke Yaman pada tahun 2003. Sebaliknya,Wakil Presiden Yaman Abduh Rabbu Mansour Hadi pernah berkunjung ke Indonesia pada tahun 2002.

Dalam kerjasama ekonomi, kedua negara telah memiliki payung hukum kerjasama ekonomi seperti Persetujuan antara Pemerintah Republik Indonesia dan Pemerintah Republik Yaman mengenai Kerjasama Ekonomi, Perdagangan, IImu Pengetahuan dan Teknik (24 Januari 1994, Sana'a), Persetujuan Perdagangan antara Pemerintah Republik Indonesia dan Pemerintah Republik Yaman (20 Februari 1998, Jakarta), Persetujuan antara Pemerintah Republik Indonesia dan Pemerintah Republik Yaman mengenai Peningkatan dan Perlindungan atas Penanaman Modal (20 Februari 1998, Jakarta), Memorandum Saling Pengertian antara Pemerintah Republik Indonesia dan Pemerintah Republik Yaman mengenai Pembentukan Komisi Bersama untuk Kerjasama Ekonomi, Ilmu Pengetahuan, Teknik dan Perdagangan (20 Februari 1998, Jakarta), dan Memorandum Saling Pengertian antara Pemerintah Republik Indonesia dan Pemerintah Republik Yaman mengenai Kerjasama Promosi Perdagangan (10 Agustus 2005, Yogyakarta).

Sejak tahun 1990 s/d 2015, hubungan perdagangan RI-Yaman telah meningkat cukup pesat. Pada tahun 1990, nilai perdagangan bilateral hanya sebesar US\$10.46 juta. Kini pada tahun 2015, volume perdagangan bilateral mencapai US $\$ 89.30$ juta. Hubungan perdagangan bilateral mencapai puncaknya sebesar US\$159.38 juta pada tahun 2013 silam sebelum terjadinya konflik bersenjata padatahun 2014 dan puncaknya pada tahun 2015 ketika dimulainya serangan udara pasukan koalisi yang dipimpin Arab Saudi.

Tanpa terjadinya permasalahan politik dan konflik bersenjata di Republik Yaman seperti pada era perang saudara Yaman (1994),Arab Spring (2011), pendudukan ibukota Sana'a oleh AlHouthi (2014), dan serangan udara pasukan koalisi Arab (2015) secara umum hubungan kerjasama perdagangan RI-Yaman menunjukkan tren yang positif. Namun demikian, nilai perdagangan tersebut 
sebenarnya masih dibawah potensinya dan dapat ditingkatkan lagi ke depannya. Sebagai gambaran, dalam hubungan perdagangan Yaman dengan negara-negara tetangga Indonesia seperti Thailand, Malaysia dan Singapura tercatat lebih besar dibandingkan Indonesia. Pada tahun 2014, hubungan perdagangan Yaman dengan Thailand mencapai (US\$1.43 milyar), Malaysia (US\$643.74 juta), dan Singapura (US\$201.65 juta). Bahkan sejumlah negara raksasa di Asia seperti Tiongkok dan India mampu menjalin perdagangan dengan Yaman dengan volume mencapai US\$5.1 milyar dan US\$1.73 milyar.

Besarnya ruang pasar di Yaman dapat dilihat dari total nilai perdagangan luar negeri Yaman sendiri. Pada tahun 2014, total nilai perdagangan luar negeri Yaman mencapai US\$14.4 milyar dan merupakan negara net importer sebesar US\$9.6 milyar. Yaman sangat mengandalkan komoditi impor untuk memenuhi kebutuhan dalam negerinya, yaitu setidaknya sekitar 80 persen kebutuhannya dipenuhi dari negara lain. Adapun barang-barang yang diperlukan terdiri dari berbagai jenis, mulai dari barang konsumsi, barang kebutuhan rumah tangga, hingga bahan bangunan, peralatan dan mesin (capital goods).

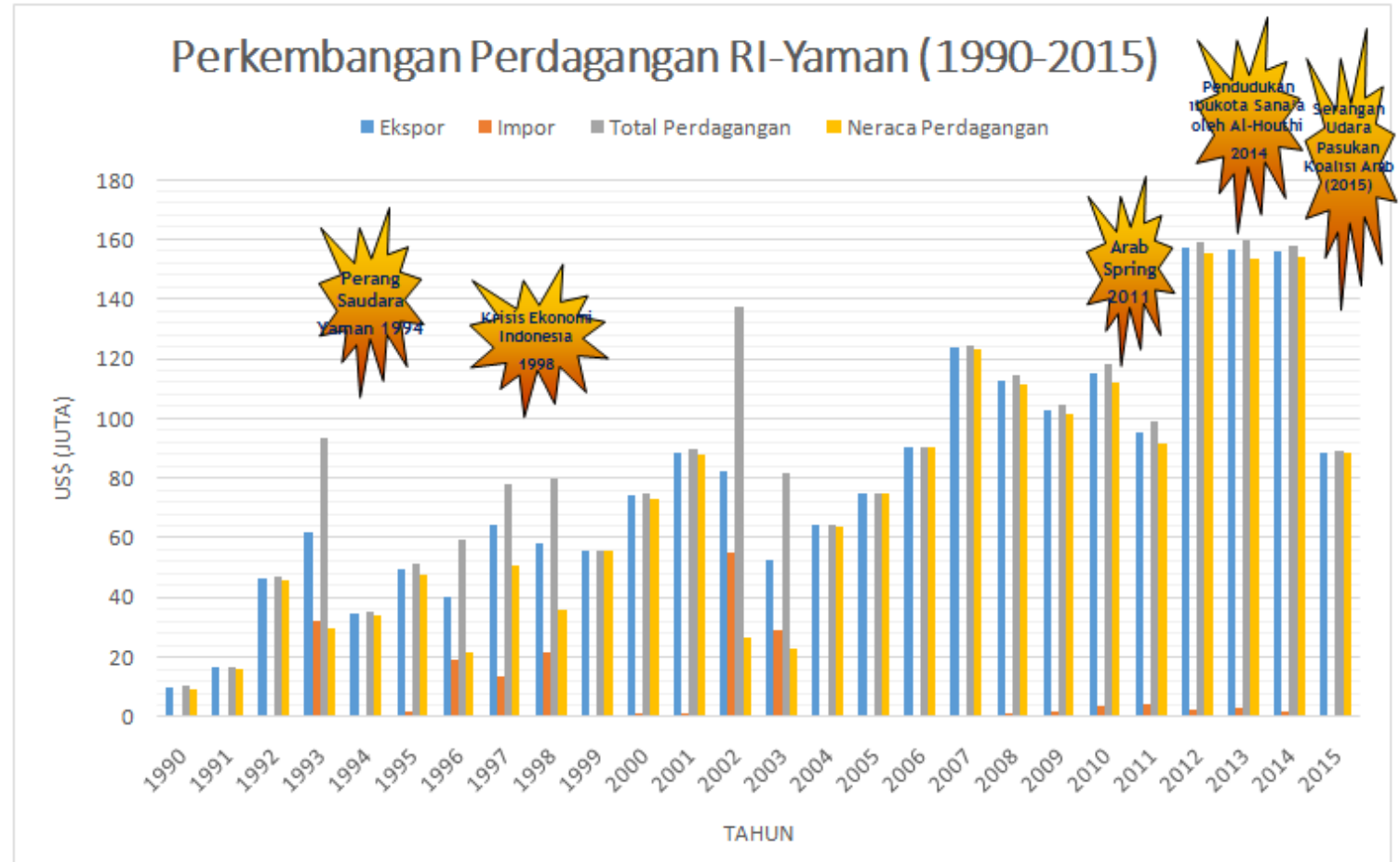

Sumber: United Nations COMTRADE dan Kementerian Perdagangan RI (2016)

Grafik 1. Perkembangan perdagangan RI-Yaman Periode 1990-2015

Pada tanggal 4 Desember 2013, Republik Yaman telah menjadi anggota ke-160 WTO pada Konferensi Tingkat Menteri ke-9 di Bali. Dan pada tanggal 28 April 2014, Parlemen Yaman telah meratifikasi protokol aksesi WTO. Maka dari itu, ke depannya Republik Yaman akan menata kembali peraturan-peraturan yang terkait perdagangan bebas dan kebijakan ekonomi Yaman diperkirakan akan semakin lebih terbuka ke depannya.Berkenaan dengan hal itu, maka akan terbuka pula peluang bagi Indonesia untuk menjajaki kemungkinan RI-Yaman Free Trade Agreement (FTA) atau 
Preferential Trade Agreement (PTA). Diharapkan tercapainya sebuah perjanjaian perdagangan FTA atau PTA bilateral tidak hanya dapat meningkatkan hubungan perdagangan kedua negara namun kerjasama ekonomi RI-Yaman pun diharapkan akan semakin lebih komprehensif.

Studi terkait kerjasama perdagangan dengan Indonesia dengan Republik Yaman dapat dikatakan masih sangat jarang ditemukan. Studi ini mencoba untuk mengevaluasi dan menelaah kemungkinan dampak liberalisasi perdagangan RI-Yaman terhadap perekonomian Indonesia dan Yaman serta menawarkan saran-saran kebijakan diplomasi ekonomi berdasarkan bukti empiris.

Teori ekonomi menyatakan bahwa liberalisasi perdagangan diharapkan diantaranya akan meningkatkan efisiensi, skala ekonomi, persaingan, produktivitas faktor dan arus perdagangan, dengan demikian, pada akhirnya meningkatkan pertumbuhan ekonomi dan kesejahteraan perekonomian di suatu negara (Barro \& Sala-i-Martin, 1995). Namun sebaliknya terdapat juga pandangan sebaliknya yakni liberalisasi perdagangan justru berdampak terhadap seperti bertambahnya defisit perdagangan (Mutakin dan Salam, 2009), menurunnya Produk Domestik Bruto (Haryadi et al, 2008), dan menurunnya daya saing ekspor (Ibrahim, Permata dan Wibowo, 2010). Terdapat berbagai kontroversi pandangan, baik dalam tataran teori maupun tataran empiris sebagaimana diuraikan di atas.

Meskipun telah terjadi reformasi perdagangan liberal di berbagai negara dan semakin banyak kerjasama perdagangan seperti dalam kerangka perdagangan bebas, Preferential Trade Agreement (PTA), danKemitraan Ekonomi Komprehensif, namun faktanya berbagai hambatan perdagangan masih terus diterapkan sehingga pada akhirnya menghambat arus perdagangan antar negara yang terlibat. Selain itu, faktor politik dan keamanan seperti lobi politik (Gawande dan Krishna, 2001) dan situasi keamanan di suatu negara, semua turut menghambat arus perdagangan antar negara yang terlibat. Seluruh hambatan ini mengakibatkan terjadinya sebuah trade gap melalui berkurangnya arus perdagangan antar negara dari tingkat potensi mereka (Kalirajan, 2007). Hal inilah yang terjadi dalam hubungan perdagangan RI-Yaman, dimana nilai perdagangan bilateral masih dibawah potensinya.

Sebagaimana telah dijelaskan pada bab sebelumnya, kerjasama perdagangan bilateral telah memiliki payung hukum sejak tahun 1994 dengan disepakatinya Persetujuan antara Pemerintah Republik Indonesia dan Pemerintah Republik Yaman mengenai Kerjasama Ekonomi, Perdagangan, Ilmu Pengetahuan dan Teknik, Persetujuan Perdagangan antara Pemerintah Republik Indonesia dan Pemerintah Republik Yaman (1998), MoU antara Pemerintah Republik Indonesia dan Pemerintah Republik Yaman mengenai Pembentukan Komisi Bersama untuk Kerjasama Ekonomi, IImu Pengetahuan, Teknik dan Perdagangan (1998), dan MoU antara Pemerintah Republik Indonesia dan Pemerintah Republik Yaman mengenai Kerjasama Promosi Perdagangan (2005).

Namun kerjasama perdagangan bilateral belum tampak membahas kerjasama liberalisasi perdagangan bilateral seperti perdagangan bebas atau bahkan sebuah kemitraan ekonomi komprehensif. Selain itu, situasi politik dan keamanan di Yaman yang semakin tidak kondusif belakangan ini telah berdampak besar terhadap kinerja perdagangan bilateral. Bahkan salah satu serangan koalisi Arab di kota Sana'a pada tanggal 20 April 2015 dengan target gudang senjata Faj Attan telah menyebabkan kerusakan berat hampir seluruh gedung di sekitarnya termasuk KBRI Sana'a dan akhirnya KBRI Sana'a diharuskan berpindah ke Salalah, Oman untuk sementara waktu.

Dalam hal ini, peran Pemerintah kedua negara menjadi semakin penting dalam turut melakukan upaya meningkatkan perdagangan bilateral. Salah satu langkah yang dapat ditempuh adalah mendorong tercapainya sebuah kerjasama liberalisasi perdagangan bilateral melalui kerangka kesepakatan perdagangan bebas. Lebih lanjut, sebagaimana dijelaskan pada bab 
sebelumnya, bahwa Republik Yaman telah menjadi anggota ke-160 WTO pada Konferensi Tingkat Menteri ke-9 pada tanggal 4 Desember 2013 lalu serta Parlemen Yaman telah meratifikasi protokol aksesi WTO pada tanggal 28 April 2014. Maka dari itu, terbuka peluang bagi Indonesia untuk menjajaki kemungkinan RI-Yaman Free Trade Agreement (FTA) atau Preferential Trade Agreement (PTA).

\section{METODE PENELITIAN}

Metode penelitian dalam makalah ini akan menggunakan pendekatan model ekuilibrium parsial yakni Software for Market Analysis and Restrictions on Trade (SMART) model untuk melihat dampak liberalisasi perdagangan RI-Yaman terhadap perekonomian Indonesia dan Yaman. Skenario liberalisasi perdagangan RI-Yaman dengan tarif nol untuk seluruh produk atau complete tariff dismantlement dengan menggunakan data perdagangan tahun 2015 (Yaman sebagai reporter) dan tahun 2013 (Indonesia sebagai reporter).

SMART model merupakan model simulasi perdagangan ekuilibrium parsial, yang digunakan untuk menilai dampak liberalisasi perdagangan atau perdagangan bebas terhadap perdagangan (trade), pendapatan tarif (tariff revenue), dan kesejahteraan (welfare effects). Perangkat SMART model ini merupakan bagian dari World Integrated Trade Solution (WITS) yang dikembangkan secara bersama-sama oleh World Bank dan United Nations Conference on Trade and Development (UNCTAD). Metode ini relatif mudah digunakan karena hanya memerlukan data perdagangan (trade flows), trade policy (misalnya tarif proteksi awal) dan nilai parameter behavioral (elastisitas) tertentu (Plummer et al, 2010).SMART model bukan sebuah perangkat baru dan telah cukup banyak penelitian yang memanfaatkan perangkat tersebut. Dalam simulasi liberalisasi perdagangan RIYaman, penulis menggunakan asumsi-asumsi sebagai berikut:

1) Partial Equilibrium: tidak ada efek pendapatan.

2) Export supply elasticity (supply elasticity) adalah perfectly elastic dimana harga dunia dari setiap produk (misalnya, apel dari Indonesia) adalah given atau sudah ditentukan. Secara default, SMART menggunakan 99 untuk infinite elasticity (elastisitas tak terhingga) untuk semua barang dan mitra negara.

3) Substitution elasticity (import substitution elasticity) yang merupakan nilai substitusi antara dua barang dari berbeda negara asal. Dalam artikel ini, SMART model dengan asumsi Armington digunakan, maka barang-barang impor dari negara yang berbeda adalah imperfect substitutes, misalnya, ikan sarden dari Yaman adalah imperfect substitutes dengan sarden dari Indonesia. Dalam SMART, import substitution elasticity adalah sebesar 1.5 untuk setiap produk.

4) Import demand elasticity bertujuan untuk mengukur respon permintaan terhadap perubahan harga impor. Nilai default adalah sama untuk semua reporters(negara) tetapi berbeda berdasarkan produknya.

5) Perfect competition (persaingan sempurna) yang artinya sebagai contoh, pemotongan tarif secara penuh terefleksi pada harga yang dibayar oleh konsumen.

Dengan asumsi-asumsi tersebut, dengan SMART model, penulis dapat mengevaluasi dampak dari perubahan kebijakan perdagangan (dalam hal ini diukur dari tarif) terhadap variabelvariabel sebagai berikut: a) Trade creation effects (perubahan impor); b) Tariff revenue effects; c) Consumer surplus (welfare); dan d) Perubahan ekspor.

Data untuk menganalisis adalah data perdagangan RI-Yaman menggunakan 6 Digit kode Harmonized System (HS) yang bersumber dari World Integrated Trade Solutions (WITS) 
(http://wits.worldbank.org) dan The United Nations Commodity Trade (COMTRADE) (http://unstats.un.org/unsd/comtrade/). UN COMTRADE merupakan database yang sangat komprehensif mengenai statistik barang dalam perdaganganinternasional.

\section{HASIL DAN PEMBAHASAN}

\section{Dampak Liberalisasi Perdagangan RI-Yaman terhadap Perekonomian Indonesia} (Analisisdengan Pendekatan Ekuilibrium Parsial - Model SMART)

Pada bab ini, hasil dengan memanfaatkan perangkat WITS/SMART model ekuilibrium parsial menggambarkan dampak dari liberalisasi perdagangan RI-Yaman dengan skenario liberalisasi penuh atau complete tariff dismantlement (tarif nol) terhadap perekonomian Indonesia dan Yaman. Adapun data perdagangan diperoleh dari Kementerian Perdagangan Yaman (Yaman sebagai reporter) menggunakan tahun 2015. Sedangkan data perdagangan dari Kementerian Perdagangan Indonesia (Indonesia sebagai reporter) menggunakan tahun 2013.

Perbedaan tahun dikarenakan ketersediaan data untuk pengolahan SMART Model di WITS database adalah Indonesia dengan data perdagangan tahun 2013, sedangkan untuk Yaman telah update dengan data tahun 2015.Secara khusus ditelaah dampak terhadap kesejahteraan, pendapatan tarif, perubahan impor dan ekspor. Dalam analisis penulis menggunakan data produkHS 6 Digit.

\section{Dampak terhadap Perubahan Kesejahteraan Masyarakat Indonesia dan Yaman (Consumer Surplus / Consumer Welfare)}

Sebagaimana telah dijelaskan dalam metodologi penelitian, kesejahteraan dapat diukur dengan melihat nilai perubahan consumer surplus.Dampak liberalisasi perdagangan RI-Yaman diprediksi akan memberikan kesejahteraan pada konsumen/masyarakat Indonesia sebesar US\$9.670. Lima produk terbesar yaitu: HS030374 (Frozen Mackerel),HS030371 (Frozen Sardines, Brisling or Sprats), HS470710 (Waste and scrap of unbleached kraft paper, paper), HS780191 (Lead unwrought containing by wt. antimony as th) dan HS780199 (Lead unwrought nes)mewakili 98.55 persen dari total peningkatan kesejahteraan masyarakat Indonesia dengan nilai sebesar US $\$ 9.530$. Berikut adalah tabel dampak liberalisasi RI-Yaman terhadap kesejahteraan masyarakat Indonesia yang diukur dengan Consumer Surplus - Top 10 Produk Terbesar.

Tabel 1. Dampak Liberalisasi RI-Yaman terhadap Consumer Surplus Indonesia (Top 10).

\begin{tabular}{clc}
\hline $\begin{array}{c}\text { Product } \\
\text { Code }\end{array}$ & \multicolumn{1}{c}{ Product Name } & $\begin{array}{c}\text { Consumer } \\
\text { Surplus in USD }\end{array}$ \\
\hline 030374 & Frozen Mackerel & 2.875 \\
030371 & Frozen Sardines, Brisling or Sprats & 2.226 \\
470710 & Waste and scrap of unbleached kraft paper, paper & 2.220 \\
780191 & Lead unwrought containing by wt. antimony as th & 1.753 \\
780199 & Lead unwrought nes & 456 \\
901590 & Parts and accessories for use with the apparatus & 51 \\
392410 & Tableware and kitchenware of plastics & 49 \\
731816 & Nuts, iron or steel, nes & 15 \\
841381 & Pumps nes & 10 \\
600129 & Looped pile fabrics of textile materials, knitt & 5 \\
\hline
\end{tabular}


Sebaliknya, liberalisasi perdagangan RI-Yaman diprediksi akan meningkatkan kesejahteraan pada konsumen/masyarakat sebesar US\$2.679 juta di Yaman. Adapuntiga produk terbesar dengan nilai consumer surplus tertinggi yaitu: HS870332 (Motor cars and other motor vehicles principally designed for the transport of persons - of a cylinder capacity exceeding 1500 cc but not exceeding 2500 cc) sebesar US\$785.718, diikuti dengan HS151190 (Palm oil (excl. crude) and liquid fractions) sebesar US\$296479, HS030239 (Fresh or chilled tunas, nes) sebesar US\$258.959.

Dilihat dari 10 produk terbesar, tampak bahwa produk otomotif Indonesia (moda transportasi pengangkutan orang) merupakan yang terbesar yakni senilai US\$1.238 juta atau 46,21 persen dari total peningkatan kesejahteraan masyarakat Yaman diikuti dengan produk perikanan (khususnya ikan tuna) sebesar US\$497.077 (atau 18,55 persen), serta produk minyak nabati (khususnya minyak kelapa sawit) sebesar US $\$ 402345$ (atau 15,01 persen).Berikut adalah tabel dampak liberalisasi RIYaman terhadap kesejahteraan masyarakat Yaman yang diukur dengan Consumer Surplus - Top 10 Produk Terbesar

Tabel 2. Dampak Liberalisasi RI-Yaman terhadap Consumer Surplus Yaman (Top 10)

\begin{tabular}{|c|c|c|}
\hline $\begin{array}{l}\text { Product } \\
\text { Code }\end{array}$ & Product Name & $\begin{array}{c}\text { Consumer } \\
\text { Surplus in USD }\end{array}$ \\
\hline 870332 & $\begin{array}{l}\text { Motor cars and other motor vehicles principally designed for } \\
\text { the transport of persons - of a cylinder capacity exceeding } \\
1.500 \text { cc but not exceeding } 2.500 \mathrm{cc}\end{array}$ & 785.718 \\
\hline 151190 & Palm oil (excl. crude) and liquid fractions & 296.479 \\
\hline 030239 & Fresh and Chilled Tunas - other & 258.959 \\
\hline 870323 & $\begin{array}{l}\text { Motor cars and other motor vehicles principally designed for } \\
\text { the transport of persons - of a cylinder capacity exceeding } \\
1.500 \text { cc but not exceeding } 3.000 \text { cc }\end{array}$ & 239.958 \\
\hline 160414 & $\begin{array}{l}\text { Prepared or preserved fish - Tunas, ski pjack and bonito } \\
\text { (Sarda spp.) }\end{array}$ & 162.397 \\
\hline 870324 & $\begin{array}{l}\text { Motor cars and other motor vehicles principally designed for } \\
\text { the transport of persons - of a cylinder capacity exceeding } \\
3.000 \mathrm{cc}\end{array}$ & 160.994 \\
\hline 151620 & Vegetable fats and oils and their fractions & 105.866 \\
\hline 870210 & $\begin{array}{l}\text { Motor vehicles for the transport of ten or more persons, } \\
\text { including the driver - with compression-ignition internal } \\
\text { combustion piston engine (diesel or semi-diesel) }\end{array}$ & 95.616 \\
\hline 030349 & Frozen Tunas - other & 75.721 \\
\hline 870322 & $\begin{array}{l}\text { Motor cars and other motor vehicles principally designed for } \\
\text { the transport of persons - of a cylinder capacity exceeding } \\
1.000 \text { cc but not exceeding } 1.500 \mathrm{cc}\end{array}$ & 51.707 \\
\hline
\end{tabular}

Sumber: World Integrated Trade Solution (2016)

Dengan simulasi diatas, dilihat dari perspektif kesejahteraan konsumen, tergambarkan kedua negara diperkirakan akan memperoleh manfaat ekonomi dari liberalisasi perdagangan bilateral. Namun masyarakat Indonesia diperkirakan akan memperoleh manfaat ekonomiyang tergolong sangat kecil sebesar US\$9.670 saja. Sementara itu, masyarakat Yaman diprediksi akan memperoleh 
manfaat ekonomi yang besar yakni mencapai US\$2.679 juta. Dalam kerangka pendekatan model ekuilibrium parsial ini, dampak ekonomi kesejahteraan belum menangkap gambaran secara keseluruhan karena perubahan producer surplus tidak dapat ditangkap dalam analisis ini.

\section{Dampak terhadap Pendapatan Tarif Indonesia dan Yaman (Tariff Revenues)}

Sebagaimana telah diprediksikan, eliminasi total tarif impor untuk produk-produk dari Yaman akan mengurangi pendapatan Pemerintah di Indonesia (dan sebaliknya).Perlu dicatat bahwa kerugian pendapatan tarif dari hasil simulasi ini adalah terkait dengan pendapatan tarif impor. Dengan skenario liberalisasi penuh RI-Yaman, perdagangan bebas RI-Yaman diprediksi akan mengurangi pendapatan tarif Indonesia sebesar US\$400.326. Kerugian pendapatan tarif terbesar oleh Indonesia adalah produk HS030371 (Frozen Sardines, Brisling or Sprats), HS780191 (Lead unwrought containing by wt. antimony as th), HS470710 (Waste and scrap of unbleached kraft paper, paper), HS030374 (Frozen Mackerel), dan HS780199 (Lead unwrought nes).Kelima produk tersebut mewakili 99,19 persen (atau senilai US\$397.117) dari total kerugian pendapatan tarif Indonesia pada tahun 2013. Berikut adalah 10 besar produk-produk asal Yaman yang berdampak terhadap penurunan tarif pendapatan Indonesia:

Tabel 3. Dampak Liberalisasi RI-Yaman terhadap Tariff Revenues Indonesia (10 Besar)

\begin{tabular}{clc}
\hline ProductCode & \multicolumn{1}{c}{ ProductName } & $\begin{array}{c}\text { Tariff Change In } \\
\text { Revenue(USD) }\end{array}$ \\
\hline 030371 & Frozen Sardines, Brisling or Sprats & -154.997 \\
780191 & Lead unwrought containing by wt. antimony as th & -130.954 \\
470710 & Waste and scrap of unbleached kraft paper, paper & -63.351 \\
030374 & Frozen Mackerel & -32.847 \\
780199 & Lead unwrought nes & -14.968 \\
901590 & Parts and accessories for use with the apparatus & -1.337 \\
841381 & Pumps nes & -483 \\
392410 & Tableware and kitchenware of plastics & -414 \\
761519 & Table, kitchen or other household articles and parts thereof & -326 \\
731816 & Nuts, iron or steel, nes & -197 \\
\hline
\end{tabular}

Sumber: World Integrated Trade Solution (2016)

Sedangkan bagi Pemerintah Yaman, liberalisasi perdagangan RI-Yaman diprediksi akan mengurangi pendapatan tarif Yaman sebesar US\$22.66 juta. Berdasarkan 10 produk terbesar,kerugian pendapatan tarif terbesar oleh Pemerintah Yaman berasal dari produk HS151190 (Palm oil (excl. crude) and liquid fractions) sebesar US\$10.88 juta, diikuti produk kendaraan bermotor sebesar US\$4.22 juta, ikan tuna (HS160414) sebesar US\$1.07 juta, roda kendaraan bermotor senilai US\$0.91 juta, serta minyak nabati (HS151620) sebesar US\$0.78 juta. Komoditas minyak kelapa sawit mewakili 48 persen dari total kerugian pendapatan oleh Pemerintah Yaman pada tahun 2013. Berikut adalah 10 besar produk-produk asal Indonesia yang berdampak terhadap penurunan tarif pendapatan Yaman: 
Tabel 4. Dampak Liberalisasi RI-Yaman terhadap Tariff Revenues Yaman (10 Besar)

\begin{tabular}{|c|c|c|}
\hline Product Code & Product Name & $\begin{array}{l}\text { Tariff Change In } \\
\text { Revenue (Juta } \\
\text { USD) }\end{array}$ \\
\hline 151190 & Palm oil (excl. crude) and liquid fractions & $-10,88$ \\
\hline 870323 & $\begin{array}{l}\text { Motor cars and other motor vehicles principally designed } \\
\text { for the transport of persons - of a cylinder capacity } \\
\text { exceeding } 1.500 \mathrm{cc} \text { but not exceeding } 3.000 \mathrm{cc}\end{array}$ & $-2,36$ \\
\hline 160414 & $\begin{array}{l}\text { Prepared or preserved fish - Tunas, skipjack and bonito } \\
\text { (Sarda spp.) }\end{array}$ & $-1,07$ \\
\hline 151620 & Vegetable fats and oils and their fractions & $-0,78$ \\
\hline 870322 & $\begin{array}{l}\text { Motor cars and other motor vehicles principally designed } \\
\text { for the transport of persons - of a cylinder capacity } \\
\text { exceeding } 1.000 \text { cc but not exceeding } 1.500 \mathrm{cc}\end{array}$ & $-0,67$ \\
\hline 401110 & $\begin{array}{l}\text { New pneumatic tyres, of rubber - of a kind used on motor } \\
\text { cars (including station wagons and racing cars) }\end{array}$ & $-0,58$ \\
\hline 870324 & $\begin{array}{l}\text { Motor cars and other motor vehicles principally designed } \\
\text { for the transport of persons - of a cylinder capacity } \\
\text { exceeding } .3000 \mathrm{cc}\end{array}$ & $-0,44$ \\
\hline 870332 & $\begin{array}{l}\text { Motor cars and other motor vehicles principally designed } \\
\text { for the transport of persons - of a cylinder capacity } \\
\text { exceeding } 1.500 \text { cc but not exceeding } 2.500 \mathrm{cc}\end{array}$ & $-0,43$ \\
\hline 401120 & $\begin{array}{l}\text { New pneumatic tyres, of rubber - of a kind used on buses } \\
\text { or lorries }\end{array}$ & $-0,33$ \\
\hline 870290 & $\begin{array}{l}\text { Motor vehicles for the transport of ten or more persons, } \\
\text { including the driver - other }\end{array}$ & $-0,32$ \\
\hline
\end{tabular}

Sumber: World Integrated Trade Solution (2016)

\section{Dampak terhadap Perubahan Impor Indonesia dari Yaman}

Dampak liberalisasi perdagangan RI-Yaman tentu akan meningkatkan impor Indonesia dari Yaman akibat penurunan harga produk impor dari Yaman. Perubahan impor merupakan trade creation effect, maka tingginya perubahan impor (dalam hal ini adanya peningkatan impor) menggambarkan besarnya trade creation effect atau dampak penciptaan perdagangan. Total perubahan impor akibat liberalisasi perdagangan RI-Yaman tahun 2013 (nol tarif) adalah diprediksi meningkat sebesar US\$729.580.

Peningkatan impor terbesar (perubahan impor) dari Yaman setelah diberlakukannya liberalisasi perdagangan RI-Yaman secara penuh adalah HS030374 (Frozen Mackere) sebesar US\$435.067, diikuti HS780191 (Lead unwrought containing by wt. antimony as th) sebesar US\$117.443, HS030371 (Frozen Sardines, Brisling or Sprats) sebesar US\$103.602, HS470710 (Waste and scrap of unbleached kraft paper, paper) sebesar US\$54.412, dan HS780199 (Lead unwrought nes) sebesar US\$16.332. Kelima produk tersebut mewakili 99,62 persen dari total perubahan impor Indonesia. Berikut adalah Tabel 10 produk impor dengan peningkatan impor terbesar (perubahan impor terbesar) setelah diberlakukannya liberalisasi perdagangan RI-Yaman. 
Tabel 5. Top 10 Produk dengan Peningkatan Impor Terbesar Setelah Diberlakukannya Liberalisasi Perdagangan Rl-Yaman 2013

\begin{tabular}{clr}
\hline ProductCode & \multicolumn{1}{c}{ ProductName } & $\begin{array}{c}\text { Import Change } \\
\text { (USD) }\end{array}$ \\
\hline 030374 & Frozen Mackerel & 435.067 \\
780191 & Lead unwrought containing by wt. antimony as th & 117.443 \\
030371 & Frozen Sardines, Brisling or Sprats & 103.602 \\
470710 & Waste and scrap of unbleached kraft paper, paper & 54.412 \\
780199 & Lead unwrought nes & 16.332 \\
901590 & Parts and accessories for use with the apparatus & 1.274 \\
841381 & Pumps nes & 394 \\
392410 & Tableware and kitchenware of plastics & 361 \\
761519 & Table, kitchen or other household articles and parts thereof & 182 \\
731816 & Nuts, iron or steel, nes & 149 \\
\hline
\end{tabular}

Sumber: World Integrated Trade Solution (2016)

\section{Dampak terhadap Perubahan Ekspor Indonesia ke Yaman}

Dengan memberikan bebas bea cukai (nol tarif) kepada Indonesia untuk masuk ke pasar Yaman, maka terbuka akses pasar yang terbesar di kawasan Jazirah dengan total penduduk mencapai 26 juta warga (per Januari 2016) yang menjadikan negara ini dengan penduduk terbesar di wilayah Jazirah Arab. Selain itu, dilihat dari sisi kekuatan ekonomi, PDB Yaman mencapai US\$35.95 milyar (2014) menjadikan negara ini sebagai ke-93 perekonomian terbesar dunia. Maka dari itu, liberalisasi perdagangan RI-Yaman akan secara signifikan mendorong peningkatan ekspor Indonesia ke Yaman. Dengan pemberlakuan liberalisasi perdagangan RI-Yaman tahun 2015, diprediksi terjadi peningkatan ekspor Indonesia ke Yaman sebesar US\$29.04 juta.

Adapun 2 produk ekspor utama dengan peningkatan ekspor Indonesia terbesar (perubahan ekspor) ke Yaman adalah: produk HS151190 (Palm oil (excl. crude) and liquid fractions) sebesar US\$6.53 juta, dan HS870332 (Motor cars and other motor vehicles principally designed for the transport of persons - of a cylinder capacity exceeding $1.500 \mathrm{cc}$ but not exceeding $2.500 \mathrm{cc}$ ) sebesar US\$6.32 juta. Kedua produk ekspor tersebut mewakili 44,24 persen dari total peningkatan ekspor Indonesia ke Yaman.

Konsumen Yaman memperoleh manfaat ekonomidari perdagangan bebas (liberalisasi perdagangan) dengan terbukanya akses untuk membeli produk Indonesia dengan harga yang lebih murah dan memperoleh manfaat dengan adanya peningkatan standar hidup. Berikut adalah Tabel 10 produk ekspor dengan peningkatan terbesar akibat diberlakukannya liberalisasi perdagangan RIYaman.

Tabel 6. Top 10 Produk dengan Peningkatan Ekspor Terbesar Setelah Diberlakukannya Liberalisasi Perdagangan RI-Yaman

\begin{tabular}{clc}
\hline ProductCode & \multicolumn{1}{c}{ ProductName } & $\begin{array}{c}\text { ExportChangelnRevenue } \\
\text { in USD }\end{array}$ \\
\hline 151190 & Palm oil (excl. crude) and liquid fractions & 6.538 .226 \\
870332 & $\begin{array}{l}\text { Motor cars and other motor vehicles principally designed for } \\
\text { the transport of persons - of a cylinder capacity exceeding } \\
\end{array}$ & 6.329 .708 \\
& \\
\hline
\end{tabular}


Tabel 6. Lanjutan

\begin{tabular}{|c|c|c|}
\hline ProductCode & ProductName & $\begin{array}{l}\text { ExportChangelnRevenue } \\
\text { in USD }\end{array}$ \\
\hline 030239 & Fresh and Chilled Tunas - other & 1.785 .127 \\
\hline 151620 & Vegetable fats and oils and their fractions & 1.691 .396 \\
\hline 870323 & $\begin{array}{l}\text { Motor cars and other motor vehicles principally designed for } \\
\text { the transport of persons - of a cylinder capacity exceeding } \\
1500 \text { cc but not exceeding } 3000 \text { cc }\end{array}$ & 1.628 .231 \\
\hline 870324 & $\begin{array}{l}\text { Motor cars and other motor vehicles principally designed for } \\
\text { the transport of persons - of a cylinder capacity exceeding } \\
3000 \mathrm{cc}\end{array}$ & 1.102 .819 \\
\hline 540834 & Woven fabrics of artificial filaments yarn - Printed & 969.779 \\
\hline 160414 & $\begin{array}{l}\text { Prepared or preserved fish - Tunas, skipjack and bonito } \\
\text { (Sarda spp.) }\end{array}$ & 727.533 \\
\hline 870210 & $\begin{array}{l}\text { Motor vehicles for the transport of ten or more persons, } \\
\text { including the driver - with compression-ignition internal } \\
\text { combustion piston engine (diesel or semi-diesel) }\end{array}$ & 646.764 \\
\hline 480431 & $\begin{array}{l}\text { Unbleached Kraft Paper and paperboard, in rolls or sheets- } \\
\text { unbleached }\end{array}$ & 504.926 \\
\hline
\end{tabular}

Sumber: World Integrated Trade Solution (2016)

\section{PENUTUP}

Selama periode 1990-2015, hubungan perdagangan RI-Yaman telah meningkat cukup pesat. Hubungan perdagangan bilateral mencapai puncaknya pada tahun 2013 silam sebelum terjadinya konflik bersenjata di Yaman pada tahun 2014 dan puncaknya pada tahun 2015. Terlepas dari tren yang positif dalam hubungan perdagangan bilateral RI-Yaman setidaknya hingga tahun 2013, namun nilai perdagangan tersebut sebenarnya masih dibawah potensinya dan dapat ditingkatkan lagi ke depannya.Dalam upaya untuk menggenjot nilai perdagangan bilateral, salah satu langkah kebijakan yang dapat ditempuh adalah menjalin kerjasama perdagangan bebas bilateral. Tulisan ini mencoba mengevaluasi kemungkinan dampak liberalisasi perdagangan RI-Yaman terhadap perekonomian Indonesia dan Yaman. Hasil simulasi dampak liberalisasi perdagangan RIYaman pada tahun 2013 terhadap perekonomian Indonesiamenggambarkan dampak yang sangat positif, sedangkan simulasi liberalisasi perdagangan RI-Yaman pada tahun 2015 terhadap perekonomian Yaman secara umum memberikan dampak positif, kecuali implikasi terhadapkerugian pendapatan tarif impor yang besar.

Dilihat dari keuntungan ekonomi bagi masyarakat (consumer surplus), maka masyarakat Yaman diprediksi akan memperoleh manfaat ekonomi yang jauh lebih besar dibandingkan masyarakat Indonesia. Namun sebaliknya, jika dilihat dari besaran kerugian pendapatan tarif impor, maka dalam hal ini kerugian di pihak Yaman jauh lebih besar ketimbang Pemerintah Indonesia. Selain itu, dilihat dari nilai perubahan perdagangan, tergambarkan bahwa liberalisasi perdagangan RI-Yaman akan membuka lonjakan ekspor Indonesia ke Yaman yang cukup signifikan. Sementara ekspor produk Yaman ke Indonesia juga diperkirakan akan meningkat, namun dengan nilai ekspor yang lebih rendah dibandingkan Indonesia. Dari seluruh analisa diatas, tergambarkan bahwa manfaat ekonomi terbesar dari liberalisasi perdagangan RI-Yaman berasal dari peningkatan ekspor Indonesia ke Yaman yang mencapai US\$29.04 juta. 
Melihat peluang potensi pasar dan ekonomi tersebut, Republik Yaman seyogyanya mendapatkan satu tempat sebagai salah satu negara 'target' dalam diplomasi ekonomi Indonesia. Salah satu langkah diplomasi ekonomi Indonesia adalah menjalin perdagangan bebas atau PTA dengan Republik Yaman.Konflik di Yaman memang masih terus berkelanjutan hingga saat ini dan berdampak cukup besar terhadap hubungan perdagangan kedua negara. Akan tetapi di sisi lain, terdapat harapan peluang bilamana tahun 2016 atau tahun-tahun mendatang perang berakhir dan program rekonstruksi Yaman mulai dilaksanakan, maka kerjasama ekonomi diperkirakan akan kembali normal. Rekonstruksi Yaman bilamana konflik senjata sudah berakhir akan memberikan peluang keuntungan ekonomi bagi negara-negara lain. Apalagi Yaman sebagai negara net importir maka sebagian besar kebutuhan akan diimpor dari negara lain. Dalam rangka memanfaatkan peluang ekonomi paska konflik senjata, maka Indonesia perlu mengantisipasi dengan baik, antara lain menyiapkan payung hukum yang dapat melindungi perdagangan kedua negara, menginventarisir daftar barang yang dibutuhkan oleh Yaman, memberikan harga yang bersaing, membuat barang dengan kualitas yang baik, pengiriman barang yang tepat waktu, dan persiapan Sumber Daya Manusia (SDM) yang dapat membantu pemanfaatan/penggunaan barang. Terkait liberalisasi perdagangan, sepatutnya kerjasama perdagangan bebas bilateral dapat dijajaki sedini mungkin sebelum negara lain lebih dahulu mengembangkan sayap kerjasama perdagangan bebas atau bahkan kerjasama kemitraan ekonomi komprehensif dengan Republik Yaman.

Indonesia sebenarnya telah memiliki sejumlah modal besar dibandingkan banyak negara lainnyauntuk terus meningkatkan hubungan kerjasama bilateral di berbagai bidang. Ditinjau dari segi sejarah, kedua negara memiliki keterikatan emosional yang cukup kuat dimana sejak abad ke-11 telah mulai melakukan kontak dengan penyebaran agama Islam yang dibawa oleh para pedagang dan penyiar Islam dari Yaman di Indonesia. Selain itu, terdapat warga Indonesia keturunan Arab Yaman di Indonesia yang diperkirakan mencapai 9 juta orang. Di bidang politik, Yaman merupakan salah satu negara Arab pertama yang mengakui kemerdekaan RI dan dalam hubungan bilateral Pemerintah Yaman mendukung penuh Negara Kesatuan Republik Indonesia (NKRI) serta hampir selalu mendukung pencalonan Indonesia di berbagai forum internasional. Pemerintah Yaman selalu menganggap Indonesia sebagai brotherly country. Dengan segenap kelebihan modal diatas, kedua negara sepatutnya mendapatkan peluang dan ruang yang lebih besar guna mengembangkan kerjasama bilateral di berbagai bidang dan bahkan tidak lagi sekedar sebuah mitra biasa akan tetapimenjadikan status kemitraan ini menjadi sebuah kemitraan komprehensif, yang dapat dimulai terlebih dahulu dari sebuah kemitraan ekonomi komprehensif.Sebagai gambaran, per Desember 2013, Republik Yaman telah menjadi anggota ke-160 WTO, diikuti dengan meratifikasi protokol aksesi WTO oleh Parlemen Yaman pada tahun berikutnya. Republik Yaman telah menandatangani perjanjian perdagangan bebas seperti Greater Arab Free Trade Area (GAFTA) dan PTAs seperti Generalized Syetem of Preferences (GSP) dan Duty-Free Treatment for Least Developing Countries (LDCs). Menurut General Investment Authority Yemen (2016), terdapat lebih dari 60 perjanjian dan protokol perdagangan dan investasi yang telah ditandatangani oleh Pemerintah Yaman. Maka dari itu, liberalisasi perdagangan bukanlah hal baru bagi Pemerintah Yaman dan oleh karena itu, guna meningkatkan hubungan perdagangan RI-Yaman kiranya dapat dipertimbangkan penjajakan kerjasama perdagangan dalam bentuk sebuah perdagangan bebas bilateral. Sebagaimana disampaikan diatas, penghapusan hambatan tarif kedua negara diprediksi akan secara keseluruhan berdampak positif terhadap perekonomian kedua negara.

Hambatan tarif memang bukanlah satu-satunya faktor yang mempengaruhi kinerja nilai perdagangan kedua negara. Terdapat sejumlah faktor-faktor lainnya yang turut berpengaruh 
terhadap performa hubungan perdagangan bilateral antara lain seperti hambatan non-tarif, situasi politik, keamanan dan ekonomi kedua negara, jumlah diaspora, dan bahkan hingga hal-hal seperti keberadaan KBRI Sana'a yang saat ini berkedudukan diluar negara akreditasi dan kebijakan pemberian visa kepada masyarakat Yaman yang bermaksud berkunjung keluar negeri termasuk ke Indonesia. Namun demikian, setidaknya penghapusan hambatan tarif melalui liberalisasi perdagangan bilateral ini dapat menjadi salah satu langkah kebijakan yang kiranya dapat dipertimbangkan ke depannya mengingat potensi manfaat ekonomi yang dapat diraih oleh kedua negara.

\section{REFERENSI}

Barro, R., \& Sala-I-Martin. (1995). Economic growth, New York, McGraw-Hill.

Gawande, K., \& P. Krishna. (2001). The political economy of trade policy: Empirical approaches, working papers, economics department, Brown University, Providence.

General Investment Authority Yemen. (2016). Free trade \& investment agreements, general investment authority website. Dapat diakses pada situs: http://www.investinyemen.org/content.php?c=1\&langid=2\&pageid=3

Haryadi, Oktaviani, R., Tambunan, M., \& Achsani, N. A. (2008). Dampak penghapusan hambatan perdagangan sektor pertanian terhadap kinerja ekonomi negara maju dan berkembang. Jurnal manajemen dan pembangunan, vol. 7, no. 2. April-Juni 2008. Dapat diakses pada situs: http://haryadikamal.files.wordpress.com/2010/07/dampak-penghapusan-hambatanperdagangan-sektor-pertanian.pdf

Ibrahim, Meily lka Permata, \& Wahyu Ari Wibowo. (2010). Dampak pelaksanaan ACFTA terhadap perdagangan internasional Indonesia. Buletin ekonomi moneter dan perbankan. Juli, Bank Indonesia. Dapat diakses di: http://www.bi.go.id/NR/rdonlyres/8E17FA47-1493-4B36-91EDC16248D031F5/21625/lbrahim.pdf

Kalirajan K. (2007). Regional cooperation and bilateral trade flows: An empirical measurement of resistance, The international trade journal, vol. 21(2), hal.85-107.

Kedutaan Besar Republik Indonesia di Sana'a. (2016). Hubungan Bilateral Indonesia-Yaman, Portal Situs KBRI Sana'a. Dapat diakses pada situs: http://www.kemlu.go.id/sanaa/id/Pages/Hubungan-Bilateral-Indonesia-Yaman.aspx

Mutakin, F., \& Salam, A. R. (2009). Dampak Penerapan ASEAN China Free Trade Agreement (ACFTA) Bagi Perdagangan Indonesia, Economic review, no. 218, Desember.

Plummer, M.G., Cheong, D., \& Hamanaka, S., (2010), Methodology for Impact Assessment of Free Trade Agreements, Mandaluyong City, Asian Development Bank. Dapat diakses pada situs: http://aric.adb.org/pdf/FTA_Impact_Assessment.pdf

Ricklefs, M.C. (2005). Sejarah Indonesia Modern 1200-2004,Serambi, April, Jakarta.

World Integrated Trade Solution. (2016). Trade database, United nations conference on trade and development, Jenewa. Dapat diakses pada situs: http://wits.worldbank.org 